УДК 811.111 '373.2

DOI https://doi.org/10.26661/2414-1135-2021-83-19

\title{
СВОСРІДНІСТЬ АВТОРСЬКОГО ПОЕТОНІМІКОНУ В КАЗКАХ ДЖ. РОЛІНГ ТА П. ТРЕВЕРС
}

\author{
Кокнова Т. А. \\ доктор педагогічних наук, \\ дочент кафедри романо-германської філології \\ Луганський національний університет імені Тараса Шевченка \\ вул. Коваля, 3, Полтава, Україна \\ orcid.org/0000-0003-0232-0756 \\ koknovatanya@gmail.com
}

\section{Ключові слова:}

авторська казка, власні назви, поетонімізація апелятивів, зоопоетоніми, топопоетоніми, мовна гра.
У статі вивчається жанрова своєрідність авторських казок Дж. Ролінг «Гаррі Поттер та філософський камінь» та П. Треверс «Мері Поппінс» з позиції поетонімікону. У процесі дослідження авторка встановлює, що найважливішою особливістю мови як фольклорних, так і літературних казок виступає контекстуальна поетонімізація апелятивів. Проаналізовано вживання зоопоетонімів, що виступають головним поетонімічним конституентом казок про тварин не тільки у фольклорі, а й в авторській казці. Аналіз матеріалу казок свідчить, що в багатьох авторських казках поетонімічних апелянтів набагато більше, ніж особистих імен. Авторка вважає, що в системі власних назв фантастичних і літературних казок специфічною $є$ емоційно-експресивна функція, за допомогою якої створюються імена героїв за їхніми фізичними, біологічними, моральними, інтелектуальними характеристиками, за соціальною, національною приналежністю, родинними зв'язками. Важливою рисою, яка об'єднує фольклорну і авторську казку, є використання прийому буквального осмислення імені або ж використання імен, які говорять самі за себе. У статі наведено характерні риси, загальні для поетонімікону літературної казки (обов'язкова присутність онімізованих апелятивів; зоопоетонімів; топопоетонімів; наявність імен, створення яких пов'язане з фізичними, психічними, біологічними, моральними, інтелектуальними характеристиками персонажа; наявність вигаданих істот 3 невмотивованими іменами; соціальне розмежування імен). Авторка також розглядає поняття мовної гри, аналізує ії функцію в мові персонажів авторських казок, визначає ознаки мовної гри - гнучкість і саморегулюючу силу системного механізму, спонтанність, характеризує іiі різновиди (мовний жарт, поетонімічна, онімічна гра). У ході дослідження встановлено,що онімічнамовнаграв авторськійказціможереалізовуватися на декількох рівнях, а саме: на фонетичному, слово-утворювальному і лексичному. На фонетичному рівні мовна гра реалізується за допомогою низки прийомів, таких як анаграма, паліндром, звуконаслідування. На словотвірному рівні мовна гра проявляється в словотворчих способах суфіксації та словосполучення. На лексичному рівні мовна гра створюється завдяки розбіжності семантичного наповнення мотивуючої і мотиваційної основ в акті словотворення (обігравання внутрішньої форми власних імен, обігравання конотативних власних назв, стилізація власних імен). Зроблено висновок про те, що жанрова роль власних назв як у фольклорному тексті, так і в тексті авторської казки належить антропоетонімам, топопоетонімам і зоопоетонімам. 


\title{
THE ORIGINALITY OF THE AUTHOR'S POETONYMICON IN THE FAIRY TALES OF J. ROWLING AND P. TRAVERS
}

\author{
Koknova T. A. \\ Doctor of Pedagogical Sciences, \\ Associate Professor at the Department of Romance and German Philology \\ Luhansk Taras Shevchenko National University \\ Kovalia str., 3, Poltava, Ukraine \\ orcid.org/0000-0003-0232-0756 \\ koknovatanya@gmail.com
}

Key words: author's fairy tale, proper names, poetonymization of proper names, zoopoetonyms, topopoetonyms, language game.
The paper studies the genre originality of the author's fairy tales on the examples of the works by J. Rowling ("Harry Potter and the Philosopher's Stone") and P. Travers ("Mary Poppins") in the context of poetonymicon. In the process of the research, the author concludes that the most important feature of the language of fairy tales, both folklore and literature, is the contextual poetonymization of proper names. The use of zoopoetonyms, which are the main poetonymic constituent of fairy tales about animals not only in folk tale, but also in the author's fairy tale, is analyzed. The analytical study of fairy tales proves that poetonymic proper names are used more frequently than personal names in the most of author's fairy tales. The author believes that emotional-expressive function is specific in the system of proper names of fiction and fairy tales, as it helps to create the names of the heroes according to their physical, biological, moral, intellectual features; social, national relationship, family ties. An important common feature of folk and author's fairy tales is the use of the technique of literal interpretation of the name or the use of the so-called "speaking" names. The paper studies the features common to the poetonymicon of fairy tales (compulsory onymized proper names; zoopoetonyms; topopoetonyms; names created on the background of physical, mental, biological, moral, intellectual features of the character; fictional creatures with unmotivated names; social differentiation of names). The author also considers the concept of language game, analyzes its function in the language of the characters of author's fairy tales; defines the signs of language game (flexibility and self-regulating force of the system mechanism; spontaneity); characterizes its types (language joke, poetonymic, onymic game). In the course of the research it is defined that the onymic language game in the author's fairy tale can be applied at different levels: phonetic, word-building and lexical. At the phonetic level, the language game applies a number of techniques: anagram, palindrome, sound imitation. At the wordbuilding level, the onymic language game applies word-building techniques of suffixation and word combination. At the lexical level, the language game is possible due to the divergence between the semantic content of the motivating and motivational background in the act of word building (playing with the internal content of proper names, playing with connotative component of proper names, stylization of proper names). It is concluded that anthropoetonyms, topopoetonyms and zoopoetonyms play the genre role of proper names not only in the folktales but also in the texts of author's fairy tales.
Постановка проблеми. Вивчення мови фольклору є одним з найважливіших завдань філології. Народна казка - це класичний зразок фольклору, вона містить «вічні, незмінні цінності» [1]. Авторська або літературна казка - це жанр парадоксальний: 3 одного боку, цей жанр тяжіє до народної творчості, а з іншого - він відштовхується від неї. Авторська казка - це літературний епічний жанр у прозі або віршах, що спирається на традиції народної казки. Фольклорні казкові оповідання часто є джерелами авторських казок, казкових чи фантастичних повістей, романів. 
Однак фольклор - це неповторна художня творчість. Його своєрідність сформувалася поза межами авторської індивідуальності. Традиції фольклору безпосередньо відображені в масовій творчості. Такий характер фольклорної традиції полягає в своєрідності, що властива літературній, авторській творчості. Фольклорне коріння авторської казки легко простежити на матеріалі власних назв, навіть не беручи до уваги ані сюжет, ані композицію фольклорних і літературних казок.

Аналіз останніх досліджень i публікацій. Питання аналізу авторських казок 3 позиції їх поетонімікону розглядалися такими вченими, як Ю. Глюдзик, О. Карпенко, Ю. Карпенко, Л. Юлдашева та ін. Попри чисельність наукових розвідок, залишаються питання, що виявляються не достатньо дослідженими вченими. 3 огляду на це мета цієї статті - встановити жанрову своєрідність авторських казок Дж. Ролінг «Гаррі Поттер та філософський камінь» та П. Треверс «Мері Поппінс» 3 позиції поетонімікону. Предметом дослідження виступає авторський поетонімікон казок, а об'єктом дослідження є авторські казки Дж. Ролінг «Гаррі Поттер та філософський камінь» та П. Треверс «Мері Поппінс».

Виклад основного матеріалу дослідження. Для аналізу своєрідності поетонімікону авторських казок Дж. Ролінг та П. Треверс треба розглянути саме антропоетоніми. Аналіз особливостей вживання антропоетонімів як у фантастичній, так і у авторській казці показує, що імена персонажів в обох випадках наділені певними функціями, пов'язаними 3 необхідністю характеристики, підкреслення будь-яких ознак, притаманних даному персонажу. Вважаємо, що найважливішою особливістю мови як фольклорних, так і літературних казок $\epsilon$ контекстуальна поетонімізація апелятивів - найдавніший спосіб створення власних назв шляхом переходу загальних імен в розряд власних назв.

У фольклорних казках поетонімізація апелятивів досить часто вживається в сильній позиції, що свідчить про їх художню значущість. Прикладом цього $є$ такі імена персонажів в англійському фольклорі: Mirror, Hare, Tortoise 3 казки «Little SnowWhite». Тут ми бачимо, що важлива не тільки онімізація апелятиву, але і вживання його із зменшувально-пестливим суфіксом. Подібні імена, як правило, мають евфонічне звучання: Henny Penny. Ім'я, що додається до апелятиву, римується зі словом, що не має значення, однак сприяє створенню комічного ефекту. Далі розберемо вживання зоопоетонімів. Значна їх кількість і висока частота їх вживання в тексті $\epsilon$ відмінною рисою літератури для дітей. Зоопоетоніми $є$ головним поетонімічним конституентом казок про тварин не тільки у фольклорі, а й в авторській казці. Їх кількість можна порівняти з кількістю антропоетонімів.
Як показує аналіз фактичного матеріалу, в багатьох авторських казках поетонімічних апелянтів значно більше, ніж особистих імен із застосуванням реального англійського іменника. У англійських казках як, наприклад, у П. Треверс, крім традиційних онімізованих апелятивів the Barnacle Goose, Wolf, Stork, в даний список імен включаються також такі назви осіб за професією людей: the Butcher, the Baker. Поетонімізація абстрактних іменників відбувається у казці Дж.К. Ролінг, де зустрічається не така велика кількість онімізованих апелятивів: Owl, Muggle, Boggart та ін. Особливу підгрупу в цій групі антропоетонімів становлять імена 3 функцією, яка характеризує особистість. Звертаючись до казки П. Треверс «Mері Поппінс», не можна не відзначити примітність таких стилізованих імен, як MorningStar-Mary, Sun-at-Noonday, Fleet-as-the-Wind, які висловлюють традиційний спосіб утворення імен американських індіанців. Як відомо, такі імена асоціюються 3 найбільш видатними якостями людини. Іншими словами, ці імена характеризують героя. Так, ім'я Fleet-as-the-Wind говорить про таку якість людини, як швидкість реакції. Дослівний переклад цього імені звучить так: «Швидкий, як вітер». Sun-at-Noonday перекладається як «Полуденне сонце», а Morning-Star-Mary як «Рання пташка Мері», що свідчить про те, що людина встає рано-вранці.

Погоджуючись з О. Горбонос, ми вважаємо, що в системі власних назв фантастичної і літературної казок особливе місце займає емоційно-експресивна функція. Основними факторами, що визначають вмотивованість таких імен, $є$ фізична, біологічна, моральна, інтелектуальна характеристики особи, іiї соціальна та національна приналежність, родинні зв'язки тощо [2, с. 94]. Наприклад, в казках імена Mr. Smarty (П. Треверс), Ginny (Дж. К. Ролінг). У художній літературі склався спеціальний прийом використання дескриптивних імен, в яких власна назва вживається або 3 прикметником, або пояснюється, доповнюється іншим іменником. Н. Будур пише: «Весь художній сенс таких імен - надати за можливості влучне позначення, яскраво зобразити предмет, в одному-двох словах підкреслити його характерну сутність» [3, с. 250], наприклад: The Fat Lady, Clever Crookshans, Madam Marsh, The Dark Lord (Дж.К.Ролінг), the Bird Woman (П. Треверс).

Онімізація апелятиву досить часто трапляється і серед топопоетонімів, які у Дж.К. Ролінг включені в розповідь про Forbidden Forest. Ще однією фольклорною традицією можна вважати наявність у фольклорних та авторських казках вигаданих істот 3 невмотивованими іменами. Дж.К. Ролінг віддає перевагу таким міфічним створінням, як дракони, ельфи, гноми, кентаври, наділяючи їх 
іменами, типовими для англійського іменника. Так, дракона звуть Norbert, а кентаври мають такі людські імена: Ronan, Bane, Firenze. Також зустрічається у П. Тревер сім'я Marry-Ann, яке вважається традиційним ім'ям служниці в Англії, або Katie Nanna, що має скорочену форму Nanny (найбільш поширене ім'я служниці або гувернантки).

Своєрідність конструювання імен полягає в, так би мовити, авторській мовній грі. При зверненні до поняття мовної гри, виникає необхідність визначитися $з$ самим терміном «гра». Гра - це вид непродуктивної діяльності, де мотив лежить не в результаті їі, а в самому процесі [4, с. 115]. Дослідники відзначали, що на ранніх щаблях розвитку суспільства, а також у житті сучасних дітей гра сприяє кооперації і тренує характер, але в ході дорослішання відбувається поступове витіснення гри 3 життя дорослих драматичним мистецтвом і спортом [5]. У загальному розумінні визначення мовної гри пов'язане $з$ певними труднощами. Реалізується вона в промові з урахуванням особливостей ситуації і особливостей співрозмовника. Ефект, результат гри поодинокий, оказіональний. Однак, на думку В. Саннікова, переважно використовується традиційний термін «мовна гра», оскільки така гра заснована на знанні системи одиниць мови, норм їх використання і способів творчої інтерпретації цих одиниць [6, с. 78]. Найчастіше мовна гра пов'язана 3 вираженням в мові комічних смислів або з бажанням створити «свіжий, новий образ» [7]. Мовна гра - багатовимірний феномен, що виявляється в різних іпостасях мовної діяльності мовців [8]. Ознаками мовної гри виступають, з одного боку, гнучкість і саморегулююча сила системного механізму, а з іншого боку, спонтанність або усвідомлення творчого ставлення до мови самих їі носіїв. Мовна гра з цієї точки зору може бути розглянута як феномен лінгвокреативного мислення, яке виявляє здатність мовців до різноманітної асоціативної переробки мовних форм і значень [8].

Мовна гра завжди пов'язана 3 креативною діяльністю i має такі особливості: здатність суб'єкта до яскравого, незвичайного й ефектного вживання слова (або виразу) завжди вторинна по відношенню до знання мовної системи і володіння iii нормативними зв'язками, тобто вміння «грати словом» передбачає володіння стилістичним аспектом мови; ігровий момент в мовному спілкуванні може проявлятися лише тоді, коли той, хто говорить, здійснює цілеспрямований пошук прийомів руйнування конвенціональних мовних структур і пов'язаних з ними стереотипів мовного сприйняття; мовна гра завжди адресна, цілеспрямована і продумана саме як ефективний варіант мовного вживання; мовна гра завжди спрямована на створення мовної структури нового смислу, не знайомого слухачеві або читачеві [4, с. 117].
Асоціативний потенціал власної назви (антропонімів) може бути охарактеризований за допомогою етнокультурної та соціокультурної інтерпретаційних моделей опису [7], оскільки семантика імені визначається, зокрема, тим, що воно конотує як одиниця мови і мовлення в рамках культури певного етносу і соціуму. На думку низки вчених, в поєднанні з особистісно проєктними аспектами сприйняття власної назви цей етно- та соціокультурний базис створює «великий і якісно складний лексичний фон», що надає конкретному імені «неповторний вигляд» [9].

На фонетичному рівні мовна гра реалізується за допомогою таких прийомів, як анаграма, паліндром, звуконаслідування та інші фоносемантичні зближення слів. Ми вважаємо, що цей вид мовної гри більшою мірою притаманній англійській авторській казці. П. Треверс в казці «Мері Поппінс» використовує фоносемантичні можливості мови під час створення власних назв для своїх персонажів. Наприклад, Mr. Wigg - the name sounds exactly like the noun wig - "a head-covering of false hair means false nature of this man» [10, c. 123]. Дж. Ролінг також обіграє фонетичну форму імені. Так, ім'я привида Peeves утворене за аналогією зі звуком, який воно означає: "a loud/rude sound, like an air being let out of a balloon".

На словотвірному рівні ономастична мовна гра проявляється в словотворчих способах. По-перше, це суфіксація. Наприклад, ім'я персонажа Dudley (Dudley Dursley) містить натяк на нікчемну людину, невдаху, адже автор обігрує слово "dud" (Дж. К. Ролінг). По-друге, це словосполучення. Цим способом утворюється велика кількість периферійних онімів в авторських казках. Наприклад, Дж.К. Ролінг використовує скорочену форму назв іспитів O.W.L.s (Ordinary Wizarding Level), a також N.E. W.T.s (Nastily Exhausting Wizarding Tests).

Штучно створені назви й імена допомагають читачеві орієнтуватися в просторі авторської казки, містять в собі елемент загадковості, а в деяких випадках навіть ребус, тому читачеві потрібно докласти розумових зусиль, щоб розгадати загадку. Різновидом даного словотвірного способу служать анаграми. Так, Дж.К. Ролінг в "Harry Potter and the Chamber of Secrets" використовує словоутворювальну гру за допомогою анаграм. За допомогою перестановки літер ім'я TOM MARVOLO RIDDLE перетворюється в I AM $V O L$ AND DEMORT. У даному прикладі також реалізується ще один прийом, який приховується в самому слові RIDDLE. «Riddle» перекладається 3 англійської як «загадка», яку потрібно розгадати. Іноді автори казок вдаються до утворення нових імен, використовуючи прийом дзеркального відображення. Так, багато персонажів казки 
Дж. Ролінг створюють Mirror of Erised, тобто Mirror of Desire. Отже, поетоніми в авторських казках створюються за допомогою типових словотворчих моделей і здатні викликати у читача стилістичний (а часто і комічний) ефект.

На лексичному рівні мовна гра створюється завдяки розбіжності семантичного наповнення мотивуючої і мотиваційної основ в акті словотворення. Лексичну мовну гру можна розглядати за позиціями, про які ітиметься далі. Зокрема, це обігравання внутрішньої форми власних імен. У казці «Гаррі Поттер<...>» ім'я Bagman (Ludo Bagman) означає людину, яка отримує гроші в результаті незаконної діяльності; Gilderoy (Gilderoy Lockhart) в перекладі означає «Золотий Король»; Albus Dumbledore: AIbus значить «білий» (а він насправді білий від сивини i, крім того, добрий чарівник, не чорний маг), а Dumbledore староанглійською значить «джміль»; Drago Malfoy: Drago - сузір'я, яке виглядає як дракон, Malfoy - 3 французького «погана вірність», а взагалі означає «зло». Обігравання конотативних власних назв представлене у казці "Mary Poppins". Зокремa, Dainty David з казки має на увазі людину 3 дуже делікатним смаком, якій важко догодити. Також таке обігравання представлене у народних віршах (Uncle Vernon, «Гаррі Поттер <...>). Стилізація власних імен розглядається як літературний прийом, який відтворює особливості стилю іншої епохи, літературної течії, письменницької манери якого-небудь автора або особливості мови людини, яка належить до певної соціальної верстви.

3 лінгвістичних позицій значущою є та обставина, що прийом стилізації заснований на відтворенні (або імітації) певних фонетичних, граматичних та інших особливостей мови тієї епохи або місцевості, про яку ведеться розповідь. Різновидом стилізації з яскраво вираженою сатиричною або гумористичною спрямованістю можна вважати шаржування. В узагальненому вигляді шаржування визначається як «зображення, уявлення чого-небудь в перебільшеному сатиричному або гумористичному вигляді» [8, с 124]. Так, віднесення до nursery rhyme простежується в пісні «The Cow Who Jumped Over the Moon» 3 «Mepi Поппінс». Також заголовок «Lines Written by a Bear of very little Brain», чий компонент «Lines Written ...»- традиційний поетичний заголовок серйозних творів (наприклад, у Вордстворта: Lines Written at a Small Distance, Lines Written in Early Spring). Гумористична функція такого заголовка полягає в тому, що його вжито в дитячій поезії.

Висновки і перспективи подальших розробок. Отже, ми виявили такі різновиди поетонімічної мовної гри в авторських казках: фонетичну мовну гру, засновану на фонетичних каламбурах; словотвірну, що виявляється у суфіксації, словотворі і абревіації; лексичну, що включає імена, що «говорять» (з живою внутрішньою формою), обігравання значення багатозначного слова, обігравання значення імені, а також стилізовані власні імена. 3 проведеного дослідження можна зробити висновок про те, що жанрова роль власних назв як у фольклорному тексті, так і в тексті авторської казки належить антропоетонімам, топопоетонімам і зоопоетонімам. Розглянуті види поетонімічної мовної гри демонструють потенційну здатність поетонімів піддаватися різним змінам, а також ілюструють творчі здібності Дж. Ролінг та П. Треверс у процесі написання літературних казок. Перспективи подальших розвідок лежать у площині детального вивчення способів та прийомів створення власних імен в авторських казках.

\section{ЛІТЕРАТУРА}

1. Карпенко С. Свропейський підхід до класифікації жанру народної казки. URL: http://nbuv. gov.ua/UJRN/Mik_2014_17_1_67 (дата звернення: 05.07.2021).

2. Горбонос О. Літературні казки I. Франка та Р. Кіплінга як авторська анімалістична жанроформа: типологічний аспект. Науковий вісник Ужггородського університету, 2016. с. 93-96.

3. Будур Н. Литературная сказка Англии. Сказочная энциклопедия. Москва : ОЛМА-ПРЕСС, 2005. C. 249-253.

4. Zipes J. A fairy tale is more than just a fairy tale. Book 2.0. 2012. Vol. 2, No. 1-2. P. 113-120.

5. Baycroft T. Folklore and Nationalism in Europe During the Long Nineteenth Century. D. Hopkin (Ed.). Leiden: Brill, 2012.

6. Warner M. Once Upon a Time: A Short History of Fairy Tale. Oxford : Oxford University Press, 2014.

7. Carrassi V.A Broader and deeper idea of fairy tale: reassessing concept, meaning, and function of the most debater genre in folk narrative research. URL: https://www.folklore.ee/folklore/ vol65/carrassi.pdf (дата звернення: 05.07.2021).

8. Jacobs J. English Fairy Tales. The Pennsylvania State University. URL: http://www2.hn.psu.edu/ faculty/jmanis/joseph-jacobs/EnglishFairy-Tales. pdf (дата звернення: 05.07.2021).

9. Blanár V. Proper Names in the Light of Theoretical Onomastics. Namenkundliche Informationen. Leipzig : Leipziger Universitätsverlag, 2019. № 95/96. P. 89-157.

10. Travers P. Mary Poppins : книга для чтения на англ. яз. Київ : Ранок, 2016. 140 с.

11. Rowling J. K. Harry Potter and the Philosopher's Stone. Bloomsbury, 2000. 223 p. 


\section{REFERENCES}

1. Karpenko, S. (2014). Yevropeiskyi pidkhid do klasyfikatsii zhanru narodnoi kazky [European approach to the classification of the genre of folk tales]. URL: http://nbuv.gov.ua/UJRN/ Mik 201417167 [in Ukrainian].

2. Horbonos, $\bar{O} \cdot(\overline{2016})$. Literaturni kazky I. Franka ta R. Kiplinha yak avtorska animalistychna zhanroforma: typolohichnyi aspect [Literary tales by I. Franko and R. Kipling as the author's animalistic genre form: typological aspect]. Naukovyi visnyk Uzhhorodskoho universytetu - Scientific Bulletin of Uzhhorod University, 93-96 [in Ukrainian].

3. Budur, N. (2005). Literaturnaya skazka Anglii. Skazochnaya enciklopediya [A literary tale of England. Fairytale encyclopedia]. Moskva : OLMA-PRESS [in Russian].

4. Zipes, J. (2012). A fairy tale is more than just a fairy tale. Book 2.0. Vol. 2, 1-2, 113-120.

5. Baycroft, T. (2012). Folklore and Nationalism in Europe During the Long Nineteenth Century. D. Hopkin (Ed.). Leiden: Brill.
6. Warner, M. (2014). Once Upon a Time: A Short History of Fairy Tale. Oxford : Oxford University Press.

7. Carrassi V. (2016). A Broader and deeper idea of fairy tale: reassessing concept, meaning, and function of the most debater genre in folk narrative research. URL: https://www.folklore.ee/ folklore/vol65/carrassi.pdf .

8. Jacobs, J. (2005). English Fairy Tales. The Pennsylvania State University. URL: http:// www2.hn.psu.edu/faculty/jmanis/joseph-jacobs/ EnglishFairy-Tales.pdf.

9. Blanár, V. (2019). Proper Names in the Light of Theoretical Onomastics. Namenkundliche Informationen, 95/96, 89-157. Leipzig : Leipziger Universitätsverlag.

10. Travers, P. (2016). Mary Poppins : Kniga dlya chteniya na angl. yaz. [Mary Poppins: A book for reading in English]. Kyiv : Ranok [in Ukrainian].

11. Rowling, J.K. (2000). Harry Potter and the Philosopher's Stone. Bloomsbury. 